\title{
THE ROLE OF RELIGION AND AGRICULTURAL TECHINOLOGY IN SOCIAL TRANSFORMATION
}

\author{
M. Endy Saputro ${ }^{凶}$ \\ CRCS Universitas Gadjah Mada, Yogyakarta, Indonesia
}

\section{Info Artikel}

Sejarah Artikel:

Diterima Desember 2011

Disetujui Januari 2012

Dipublikasikan Maret 2012

\section{Keywords:}

Agricultural Technology;

Empowerment;

Peasants Community;

Religion.

\begin{abstract}
Abstrak
Tujuan penelitan ini adalah untuk mengungkapkan bagaimana agama dan teknologi pertanian dapat memberdayakan masyarakat dan mendorong sebuah transformasi sosial. Survei dan wawancara diterapkan guna mendapatkan data yang dibutuhkan dalam penelitian. Objek penelitian ini adalah komunitas petani di Banjarnegara yang tergabung dalam organisasi petani yang difasilitasi oleh organisasi massa islam Muhammadiyah. Hasil penelitian menunjukkan bahwa agama, dalam hal ini ajaran agama yang dipegang erat oleh organisasi massa Islam (Muhammadiyah) dapat meningkatkan kondisi ekonomi sebuah komunitas petani di Banjarnegara. Muhammadiyah memfasilitasi komunitas petani tersebut untuk menerapkan teknologi pertanian yang tepat sehingga dapat meningkatkan hasil panen secara signifikan. Hal tersebut menunjukkan bahwa agama dan teknologi pertanian memainkan peranan penting dalam memberdayakan masyarakat dan membawa transformasi sosial bagi komunitas petani di Banjarnegara.
\end{abstract}

\begin{abstract}
The objective of this study is to reveal how religion and agricultural technology can empower a peasant community and foster a social transformation. Survey and interview were implemented to gain the data. The object of the study was a community of peasants in Banjarnegara district that belong to a peasant organization facilitated by Muhammadiyah. The results show that religion, in this case is religious teaching tightly-hold by an Islamic mass organization (Muhammadiyah), can improve the economic condition of a community of peasants in Banjarnegara. Muhammadiyah facilitated the peasants community to apply a proper agricultural technology which can improve the crops significantly. The study conclude that religion and agricultural technology play a great role in empowering society and bring about social transformation for peasants community in Banjarnegara.
\end{abstract}

(C) 2012 Universitas Negeri Semarang

\footnotetext{
Alamat korespondensi:

CRCS Universitas Gadjah Mada, Yogyakarta, 53455

E-mail: endy.putro@gmail.com
}

ISSN 2086-5465 


\section{INTRODUCTION}

Religions take an important role to arrange for worshiping of God. Religions teach its believer to know how to going to Church or doing sholat. On the one hand, religions also have a duty to response social issues related to economics, politics, culture and environment. Religious teaching can be an important factor which can foster, facilitate awareness and bring about self-empowerment. (Bustang et.al, 2008). Religion, especially Islamic mass organization can be a very useful agent in the development of a country among any other istitutions. Islamic mass organization as non-government institution can be a balancing power and have ability in doing empowerment of society, building political, economic, and socio cultural power (Hidayat, 2008).

This paper seeks to examine the peasant community development of Muhammadiyah which is applied in Banjarnegara, a town in Central Java. It is known that poverty is a common picture in many developing countries, whose number reached more than a billion of world population, especially peasant community (Hadiyanti, 2006). In Banjarnegara, Muhammadiyah gets great success to foster the peasant's social transformation. Muhammadiyah assists the Banjarnegara peasants through empowering a new method of paddy planting which involves an agricultural modern science. From this case, I would like to state that religion plus modern science will result a great social transformation.

\section{METHODS}

This study used a qualitative approach. The study uses a qualitative approach made to understand persitiwa, activities, behaviors and events actors in certain situations and scientific (natural). This study uses qualitative metofe, because it can directly present the relationship between researchers with research subjects to be more sensitive.

According to Bogdan and Taylor, qualitative methods is a research procedure that produces descriptive data in the form of words written or spoken of the people and the observed behavior (Moleong, 2002: 2). Meanwhile, according to Sugiyono (2010: 15), a qualitative research method is a method of research that is based on the philosophy postpositivisme, is used to examine the condition of the natural object (as his opponent was an experiment) in which the researcher is a key instrument, sampling data sources conducted by purposive (if appropriate) and snowball (more in-depth data collection), collecting a triangulation technique (combined), data analysis is inductive / qualitative and qualitative research results further emphasize the significance of the generalization (Sugiyono, 2010: 15).

\section{RESULT AND DISCUSSION}

All monotheistic religions play an important role in empowering the religious members, individually and socially. Empowerment is a struggle for equality and social justice that support the possibility of the people to participate in social change. All religions believe that all humankinds are equal. In reality, clashes and competition among religions to be the superior to others is undeniable. However, they believe that all humans are equal, giving emphasize on their role in providing moral and ethical groundwork for empowerment (Cnaan, 1999: 323). Community empowerment is the act of giving motivation and encouragemnt to the community to dig their potency and dare to act to improve their quality of life, through education for creating awareness and self-ability (Ravik Karsidi dalam Wida $\mathrm{R}$ dan Suminah, 2011).

The evidence of the above statement is demonstrated by Warner's study (1993) on the living situations of religious congregation' members in America. Congregations serve not only as community of prayer but also it creates a sense of community and assisting one another. Religious organizations are key teachers of political and civic skills. Based on Cnaan study (1999), the empowerment efforts of religious organizations in America 
has been focused for example on the African American society. The black church was the place where slaves gained communal support and spiritual sustenance. The same case happened in the Hispanic community and women who active in extra-domestic sphere. The liberation theology movement has also the product of empowerment for the oppressed through the church. Religion based empowerment was not only focused on the philanthropic activities but also serves as the theology and political forces.

Religion as belief system provides human spiritual and social understanding of life. It is important to note what Durkheim (1951 in Cnaan, 1999) said that "religion provides direction and expectations as to the meaning of human existence and defines the obligations of its members to themselves, their family and the broader society". To conclude, like what have been asserted by Maton and Wells (1995: 177) that religion's role in the group empowerment is to facilitate critical awareness of oppression, to provide the alternative visions and cultural values, besides to mobilize human and institutional resources.

Social transformation as general concept can be implemented through several strategies. Each strategy is influenced by the framework of seeing social problem and the context of problem itself. The strategies are: (1). amelioration, which is done by alleviating suffering, resulted from systematic oppression and injustice by providing some material goods in a charitable manner. (2). controlling, regulating and monitoring members of subordinate groups and enforcing change in their behaviors because they are considered immoral and responsible for their own problematic situation. (3). adaptation through counseling and treatment of oppressed persons to help them adjust to, cope with, and fit into the "realities" of unjust and oppressive societies. (4). reform by advocating for changes in the system using top-down approach, and (5). structural transformation (Gil in Mulally, 2002: 205). The context of problem and resources within the people with problem are essential factor to determine the strategies used. The goal is social change and social justice for the people.

Similar to that in empowerment, the role of religion in social transformation is that religion serves as ethical source for social change. The most influential work on religious ethic was that of the Weberian protestant ethic for capitalism. Protestant ethics emphasizes industriousness, asceticism, a jealous spirit in performing tasks in everyday aspect of life, and endeavors to prevent laziness, especially in economic activities, and encourages discipline and regularity in work. Those ethics are supported by the institutionalization of religious group. Weber illustrated that for example a member of one religious group will be easily recognized and helped by the other members of the same group since they have formal identity among the members (Weber, 1982: 45).

Besides the institutionalization, one important issue of Weber's thesis is rationalization. The word 'rational' means 'organized way of thinking'. Following Morris, rationalization refers to "... the increasing systematization of religious ideas and concepts, the growth of ethical rationalism, and the progressive decline of ritual and 'magical' elements in religion" (in Abdullah, 1994: 24). The definition denotes shift of paradigm, from using magical science to applying rational science. Rational science implicitly requires systematized strategy in facing reality.

Muhammadiyah is an Islamic mass organization. It was established in Yogyakarta on November 18, 1912, by K. H. Ahmad Dahlan. Muhammadiyah, like Nahdhatul Ulama, considered believing the ahlu sunnah wal jamaah (sunni) system (Mulkhan, 2003: 46). The aims of this organization are: (1). to return (services and actions) to the Qur'an and Hadith by purifying the religion from bid'a and khurafat, (2). to interpret Islamic teachings in a modern way, and (3). to disembarrass the umat of traditional, conservative and formal elements. The super goal of this organization is the reformation of knowledge, behavior, and social institutions (Abdullah, 1994: 84).

Muhammadiyah's movements is basically based on the teaching of Shura al- 
Maun. Al-Ma'un is one of the verse (shura) from the Holy Qur'an stressing on the importance of standing on the side of the poor and do well for the orphan. People who repuls the orphan harshly is people who denies the religion. The founding of Muhammadiyah, K. H. Ahmad Dahlan, repeatedly taught this shura to his students with the reason that this shura should not only be remembered or only a discourse but it should be practice. As a result many social institutions and schools have been established by Muhammadiyah.

Dakwah jama'ah is a kind of community organizing driven by dakwah (calling to Islam) spirit. It is formed from smalls family groups consisting of five to ten families. Within that small jama'ahs (group), empowerment programs are socialized. The jama'ah is formed in a pengajian. The preacher (kyai) usually recites Qur'anic verses or hadith while explaining social orders and people behaviors. Moslems are encouraged to spend their money for zakat and sadaqah. In Peasant community, or majority of Indonesian community, the impact of Qur'anic verses as driving force to change people behaviors is still essential.

Dakwah jama'ah model has been implemented from the time of Ahmad Dahlan. He begins his activities on assisting and revitalize social network in the society. Groups' activities in this dakwah jama'ah group are limited to pengajian and understanding religious teachings only. The good point of these small groups is that they are very effective in promoting and shaping a solidarity and conformity within the group. Besides, it constructs value system in the group (MPM PPM, 2006: 34).

Based on the above assessment, dakwah jama'ah is considered to be a potential strength for popular education as well as community empowerment. Through these groups, the role of Muhammadiyah will be the driving force to transform the religious ethics and values as the élan-vital of entrepreneurship spirit in the community. Hence, the dakwah here does not merely mean call for spirituality but it also a contextual dakwah (bil hal) to empower the economic, social and psychology of the community (MPM PPM, 2006: 35).

Empowerment program of Muhammadiyah is integrated in all movement activities done by this organization. However, the more specific empowerment program which reaches out the poor community such as the peasant and fisherman is undertaken by the Majelis Pemberdayaan Masyarakat (MPM)/ the council of Community Empowerment Boards. This board is established on 2005 in the $45^{\text {th }}$ Muktamar (five years meeting). The commitment to empower the people pertinent to the concern of Muhammadiyah movements, it is to stand on the side of the grass root communities strive for the mustadzafin (the oppressed).

By the establishment of MPM (Majelis Pemberdayaan Masyarakat) Muhammadiyah, the program of empowerment is managed better. To ground thatempowermentprogram, Muhammadiyah employs ecological approach for human development. This perspective believes that social intervention for the community deals with all level of individual relation with his environment. Humans are always part of their environment. They could not live alone. Intra, and inter personal relationships play great role in shaping social relations and spirituality.

The purpose of empowerment board of Muhammadiyah are: 1) Raise people awareness on their rights and responsibilities as citizens; 2) Improvement of the basic needs and people income (especially those who are poor and marginalized); 3) Policy advocation, particularly concerning the un accommodative and insensitive public policy; 4) Development of crisis center in regional and local level as the immediate response and anticipation toward psychosocial problems in the community The philosophical basis of this movement is to grow a tadpole which can only live in a small pond into a frog which is able to jump into every place).

The empowerment board of Muhammadiyah consists of many people, with specific job description. Conceptually, in empowering the people, Muhammadiyah's 
roles are as the facilitator and the program coordinator of Muhammadiyah's empowerment; as the instigator and motivator for Muhammadiyah people to develop the pro-social and voluntarism spirit; and as the mediator of individual, environment, and the larger system.

Banjarnegara is a district in Central Java. Banjarnegara stands for banjar and Negara. Banjar means sawah (paddy field) and negara means kota (city). Thus, Banjarnegara means the city with large paddy fields. Geographically, Banjarnegara is dominated by hilly and mountainous areas. Banjarnegara district's wide is $106.970,997$ hectare, with the farming area is 70.780 hectare which is divided into wet land (rice field) with irrigation 16.024 hectare, rice field with irrigation from the rain (tadah hujan) 4.605 hectare, and dry land is 50.151 hectare (Humas SETDA Banjarnegara, 2003).

Banjarnegara is an agrarian area. The farming products of this district are potato, corn, salak, and cassava (DIPERTAN Banjarnegara, 2003). The majority people of Banjarnegara are peasant and civil servant. According to the data from BPS 2003, the number of peasants in this area is 220.259 people (54, $66 \%$ of total work force). While, the number of poor people in this district is 94.171 families $(39,93 \%$ of families in Banjarnegara). In economical matters, Banjarnegaranese attitudes are "samadya" (accepting as it is), realistic and are not ambitious. It is proven by the majority of the people working as civil servant or peasant, the less dynamic jobs. The success measurement is not based on the economic achievement but in the gotong royong culture within them.

The peasants who involve in the community of Muhammadiyah empowerment are grouped into a Jama'ah Petani (peasant community). The word jama'ah is used to define a religious community or congregation. That jamaah's name is "Surya Jaya Sentosa" (SJS). The aim of this organization is

memberdayakan masyarakat petani agar memiliki daya untuk berjama'ah, berperilaku, dan berteknologi dalam olah tani untuk menigkatkan pendapatan dalam rangka mewujudkan kemakmuran dan kesejahteraan diri, al-Islam dan Umatnya (Maksum, 2007: 9).

Before the establishment of jamaah petani, some Muhammadiyah's activists have long dealt with peasant community. The experience make Muhammadiyah aware that to mange an empowerment program needs a system to support. After the Muktamar $45^{\text {th }}$ in Malang, Muhammadiyah launch an empowerment council, and begins to spread its ideas to its branches and districts. The Muhammadiyah district leaders in Banjarnegara were aware that this empowerment will be meaningful for the peasants. Consequently, they ask for trainings and assistance from the central MPM to share them knowledge of farming. The local people design the program, and Muhammadiyah facilitate them.

By the implementation of this program, the empowerment model of Muhammadiyah in peasant community is formulated. The purpose of this empowerment is not only increasing peasant income or reducing the cost of production to increase the production through good farming system, but also how to help the poor be independence economically and then capable to pay zakat to help other destitute. The idea is "empowerment for empowerment".

This empowerment programs are directed to all farmers with all kinds of plants. Such as, Crops, horticulture, commercial agricultural plantations, herbs, and animal husbandry as well as fishery farmers (Maksum, 2007: 3-4). This empowerment program covers four domains. They are organizational, behavioral, technological, and production empowerment. There are two systems employed in this empowerment program, that is rolling on system and rotating system.

Rolling on means the empowerment will last in certain period of time, and then the empowerment is rolled on other community which has not been empowered yet. The aim is even distribution. Muhammadiyah gives a seed capital to the community, but 
the organization does not demand any profit from this program. After the period completed, the capital should be given back to the organization and will be allocated to assist other areas (Maksum, 2007: 5).

The second system is rotating. This means empowerment is aimed to empower others. In this level, empowerment process is not limited to certain period. However, the community has to share the profit to the organization. The profit will be used to empower the other. There are two ways in managing the profit sharing fund from empowerment. The first is the community should pay infaq, zakat and entrepreneurs share through the organization. And the second, the organization use the funds from infa $q$ and zakat to help the asnaf (eight group of people who are eligible to receive zakat funds) (Maksum, 2007: 5).

The pressure to fulfill the growing need of food for citizens has made many countries try to improve food production. Therefore, a better agricultural technology should be developed and introduced continuously to the peasants so that they can apply the technology to improve food production (Sadono, 2008).

The process of cultivating rice field is the main issue of agricultural technology of Banjarnegara. Farmland of Banjarnegara is progressively reduced by housing of resident. It causes a difficulty to enlarge the farmland. Conversely, the product of agriculture demands an additional income. To solve it, the government usually has two programs, i.e. vitalisasi and refitasi. The two programs are acts of fertilize and re-fertilize soil. To shorten fund and time, MPM creates a new type of manure named PLK(Pupuk Lengkap Kocoran/ Complete Kocoran Manure). Comparing with the kompos, PLK can substitute 20 ton kompos for 1 ton. PLK shorten the time as well. The farmland should not wait up to twenty years for implanting, yet just for twenty days the land ready to implant again. Another benefit is the peasant itself can produce the kocoran manure because they were taught the very details of how to make it (Maksum, 2007: 76). They were also guided how to use the manure effectively to improve crops.
Although the kocoran manure takes an important role in term of the agricultural technology, yet it is nothing, if it is not followed by preparing the good quality of paddy seed. Arranging a good irrigation is important aspek to be taught to the peasants. The process of planting the seed is also a matter of concern. There are many directions that should be followed to plant correctly, such as giving enough space for each plant to ensure the sufficiency of nutrients and sun rise.

The program of empowerment for the peasant in Banjarnegara has been proven to be successful. It can be seen from the improvement of crops before and after applying the cultivating method given by the empowerment program. Many peasants get the benefit of the program. "Dengan upaya sendiri masyarakat telah melakukan revolusi pertanian di tengah-tengah pesimisme untuk menaikkan produksi beras," said Anton Apriantono, Minister of Agriculture Affairs, in the harvest of Banjarnegara (Republika, 11 Maret 2007). This success is not only increasing the income of the peasant, but also revoluting the social condition in Banjarnegara.

\section{CONCLUSION}

Majelis Pemberdayaan Masyarakat Muhammadiyah has helped to foster social transformation in Banjarnegara. There are at least two factors of fostering this social transformation. First is empowerment program while the second is the application of agricultural technology. The firs point will not be successful without the second, because the peasant in fact can empower himself. What is need by the peasant is the agricultural technology which requires rational knowledge. However, the second without the first will trap into long duration to be successful, since it is difficult to convince the peasant without empowering him continuously. Therefore, the empowerment of Muhammadiyah plus the agricultural technology brings about social transformation. 


\section{REFERENCES}

Bustang, et. al. 2008. Potensi Masyarakat dan Kelembagaan Lokal dalam Pemberdayaan Keluarga Miskin di Pedesaan (Studi Kasus di Kabupaten Bone). Jurnal Penyuluhan. 4.

Cnaan, R. A. 1999. Empowerment through Organized Religion, in Wes Shera and Lilian Wells (eds.), Empowerment Practice in Social Work: Developing Richer Conceptual Foundations, Ontario: Canadian Scholar Press.

Hadiyanti, P. 2006. Kemiskinan dan Upaya Pemberdayaan Masyarakat. Komunitas, Jurnal Pengembangan Masyarakat Islam. 2 (1): 60-70.

Hidayat, M. 2008. Ormas Keagamaan dalam Pemberdayaan Politik Masyarakat Madani. Komunitas, Jurnal Pengembangan Masyarakat Islam. 4 (1): 10:20.

Listiyani. T. 2011. Partisipasi Masyarakat Sekitar dalam Ritual di Kelenteng Ban Eng Bio Kecamatan Adiwerna. Jurnal Komunitas. 3 (2): 1-8.
Maksum, D. 2007. Pemberdayaan Petani Versi Muhammadiyah, Banjarnegara: Ikmalana.

Maton, K. I. and Wells, E. A. 1995. Religion as a community resource fro well-being: prevention, healing, and empowerment pathways, in Journal of Social Issues. 51: 177-193.

MPM PP Muhammadiyah. 2006. Buku Materi Rakernas \& Forum Kemitraan Pemberdayaan Masyarakat Majelis Pemberdayaan Muhammadiyah.

Mulkhan, A. M. 2003. Islam Sejati Kiai Ahmad Dahlan dan Petani Muhammadiyah, Yogyakarta: Serambi.

Sadono, D. 2008. Pemberdayaan Petani: Paradigma Baru Penyuluhan Pertanian di Indonesia. Jurnal Penyuluhan. 4.

Warner, S. R. 1993. Work in progress toward a new paradigm for the sociological study of religion in the United States, in American Journal of Sociology. (98) 1044-1093. 